( Т. Ю. Киричок, д-р техн. н., проф., В. А. Баглай, асп., КПІ ім. Ігоря Сікорського, А. А. Безпалий, канд. техн. наук, старш. фахівець служби досліджень та розвитку технологій Банкнотно-монетного двору Національного банку України

\title{
ВПЛИВ ТЕХНОЛОГІЧНИХ ПАРАМЕТРІВ НА ВЛАСТИВОСТІ ДРУКУВАЛЬНИХ ЕЛЕМЕНТІВ ФОРМ ІНТАГЛІОДРУКУ, ОТРИМАНИХ ПРЯМИМ ЛАЗЕРНИМ ГРАВІЮВАННЯМ
}

Дослідження методом оптичної металографії шліфів гравійованих штрихів тридцяти видів, що відрізнялися запроектованим профілем (глибиною (20-100 мкм), шириною (30-100 мкм), кутом нахилу стінок штриха $\left.\left(60^{\circ}-90^{\circ}\right)\right)$ та потужністю гравіювання, утворених методом

DLE на латунній пластині, показало, що всі гравійовані штрихи зразка мають суттєві відхилення від заданого геометричного профіля і зазвичай є несиметричними. Оскільки стан поверхні штрихів є ще одним додатковим фактором забезпечення зносостійкості форм DLE + PVD, то для урахування цього параметру було розроблено принципи бального оцінювання поверхні штрихів на основі порівняння зі зразком за 5-бальною шкалою.

Ключові слова: інтагліодрук; пряме лазерне гравіювання; друкувальні елементи; гравійовані штрихи; тиражостійкість; латунь.

\section{Постановка проблеми}

Інтагліодрук, який, як мистецтво, з'явився понад 400 років тому, вже десятиліття не здає своїх позицій, оскільки забезпечує одну 3 найбільш розпізнаваних населенням захисних ознак захищеної поліграфічної продукції, зокрема, банкнотної [1-5] - високотактильний рельєф. Цьому сприяють також усталені традиції банкнотного виробництва [6, 7], а також обов'язковість цього виду друку для використання на банкнотах $[8,9]$ Незважаючи на традиційність цього методу захисту, технологія інтагліодруку постійно розвивається, зокрема і щодо удосконалення процесу виготовлення друкарських форм. Вже майже два десятиріччя зусилля розробників спрямовані на розвиток найсучаснішої технології виготовлення форм інтагліодруку прямого лазерного гравіювання (DLE - Direct Laser Engraving) [10-16]. Лазерне гравіювання $\epsilon$ першим, не рахуючи етапу дизайну форм, етапом технологічного процесу, під час якого мають

() Автор(и) 2020. Видавець КПІ ім. Ігоря Сікорського.

CC BY 4.0 (https://creativecommons.org/licenses/by/4.0/). 
бути максимально дотримані запроектовані параметри гравійованих штрихів, котрі визначають як тактильність відбитків (ключову захисну ознаку, яку забезпечує інтагліодрук), так і їх колірні характеристики. Тому визначення якості відтворення гравійованих штрихів та її залежності від запроектованих параметрів профілює актуальним завданням, що дозволить удосконалити режими оброблення форм DLE та розширить її використання у виробництві захищеної поліграфічної продукції.

\section{Аналіз попередніх досліджень}

Розвиток технології DLE зумовлений кількома факторами. Найпершою причиною є прагнення суттєво скоротити час виготовлення форм [10-16]. Так, якщо традиційний спосіб виготовлення форм, що включає виготовлення оригіналу ручним гравіюванням, гальванічного тиражування матриці, монтування копій з отриманням збірної форми [10] потребує кількох стадій гальванопластики, ретушування та триває до 48 днів. Хоча традиційні методи, як правило, дозволяють отримати ідеальну копію пластини-оригіналу, дрібні дефекти під час електроформування, вимагають ретельного огляду пластин та ретушування кваліфікованими граверами: це суттєво збільшує час та витрати на виготовлення форм [11]. Тоді як лазерне гравіювання дозволяє скоротити час на виготовлення форми до трьох днів. Ще однією причиною, як зазначено розробниками обладнання для DLE, $є$ те, що якість друку визначається, зокрема, й відтворенням запроектованого профілю гравійованого штриха. Оскільки технологія DLE, незважаючи на низку переваг та технологічних можливостей порівняно з іншими технологіями [17], має певні особливості, що можуть викликати зниження тиражостійкості форм порівняно із традиційними технологіями виготовлення форм: обробку латунної пластини лазером та подальше нанесення захисного нітрид-хромового покриття вакуумним напиленням (PVD). Тому технологія прямого лазерного гравіювання з подальшим нанесенням захисного нітрид-хромового покриття PVD потребує удосконалення режимів оброблення форм та PVD. У попередніх дослідженнях нами проаналізовано та визначено основні групи факторів, які впливають на тиражостійкість форм інтагліодруку: параметри процесу DLE (спосіб видалення напливів металу в процесі лазерного гравіювання); параметри форми інтагліодруку (спосіб виготовлення (традиційний чи DLE), параметри штрихів форми інтагліодруку (їх ширина, довжина, глибина, відстань між штрихами, вид профілю (трапецієподібний, прямокутний), симетричність профілю (симетричний, асиметричний); параметри процесу вакуумного напилення (температура підложки форми під час напилення), шорсткість пробільних та друкувальних елементів, товщина нітридхромового покриття, режимів травлення підложки в камері напилення, відсотковий склад газової суміші $\mathrm{Ar}-\mathrm{N}_{2}$ в камері напилення) [17]. 
Отже, достовірне визначення взаємозв'язку параметрів гравійованих штрихів форми з технологічними параметрами DLE дозволить цілеспрямовано впливати на тиражостійкість форм інтагліодруку.

\section{Мета роботи}

Визначення взаємозв'язку параметрів гравійованих штрихів форми з технологічними параметрами DLE задля визначення напрямів цілеспрямованого формування тиражостійкості форм інтагліодруку.

\section{Результати проведених досліджень}

Модельна форма з вісьмома плашками, кожна з яких являє собою сукупність 30 гравійованих штрихів - прямокутного та трапецієподібного профілю, шириною від 30 до 100 мкм, глибиною від 20 до 100 мкм (параметри наведено в роботі [18]) запроектовано і виготовлено фахівцями Банкнотно-монетного двору Національного банку України з використанням системи прямого лазерного гравіювання Jura JSP Direct Laser Engraver (тип лазера - неодимовий (Nd:YAG, алюмо-іттриєвий гранат легований іонами неодиму); довжина хвилі 1064 нм; потужність 1,77 кВт; матеріал пластини - латунь; товщина пластини 0,977-1,032 мм, область гравіювання - 54×54 мм. Для проведення досліджень на латунній пластині із використанням різних режимів лазерного гравіювання (режими: H3L - видаляє шар товщиною 2 мкм за прохід; НЗМ - видаляє шар товщиною 4 мкм за прохід; НЗН - видаляє шар товщиною 8 мкм за прохід) було вигравійовано вісім ідентичних ділянок (плашок) з набором друкувальних елементів 3 різною геометрією поперечних профілів [18].

Із зазначених ділянок відповідно до стандартних методик підготовлено металографічні шліфи перпендикулярно до площини пластини і гравійованих штрихів. Одержані в такий спосіб зразки досліджені за допомогою фотомікроскопа віддзеркаленого світла Neophot-32, який дає можливість досліджувати травлені та нетравлені мікрошліфи та фотографувати їх зі збільшенням до ×1000 [19-23].

Оскільки стан поверхні штрихів $€$ ще одним додатковим фактором забезпечення зносостійкості форм DLE + PVD, то для урахування цього параметру було розроблено принципи бального оцінювання поверхні штрихів на основі порівняння зі зразком за 5-бальною шкалою: 0 - найкращий зразок, 4 - найгірший. Принципи експертного оцінювання наведено в табл.

\section{Результати дослідження}

зразків форм інтагліодруку

Встановлено, що всі гравійовані штрихи зразка мають суттєві відхилення від заданого геометричного профіля і зазвичай $€$ несиметричними.

Незважаючи на суттєві відмінності профіля, що був отриманий гравіюванням і запроектованого, з погляду можливої тактильності відбитків (найсуттєвішого параметру інтагліодруку). Переважна більшість режимів виготовлення і профілів забезпечує достатньо високу відповідність фактичної 
ТЕХНО ЛОГ І Ч Н П П РО ЦЕ С И

Система бальної оцінки форми стану поверхні стінок гравійованих штрихів форми без покриття

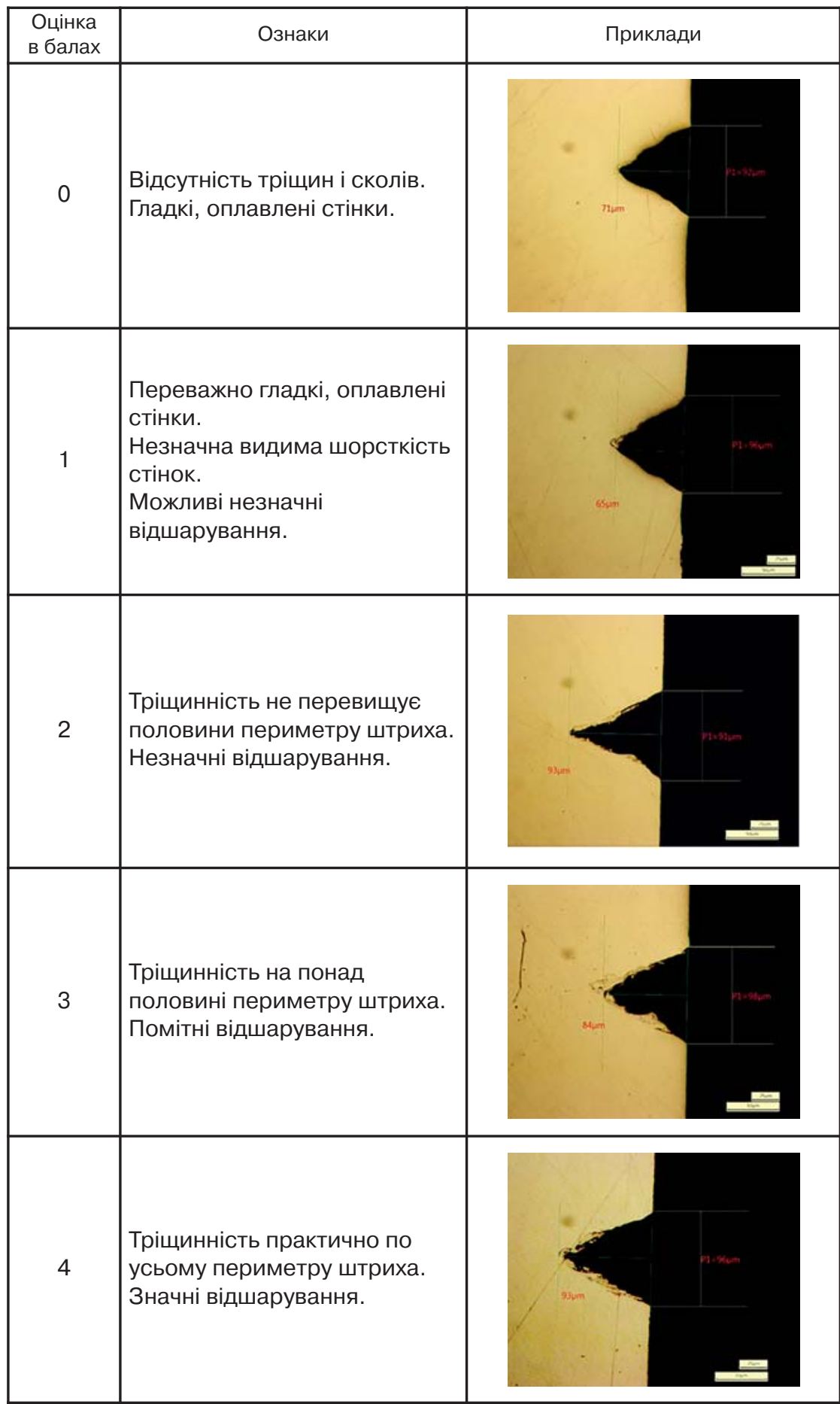




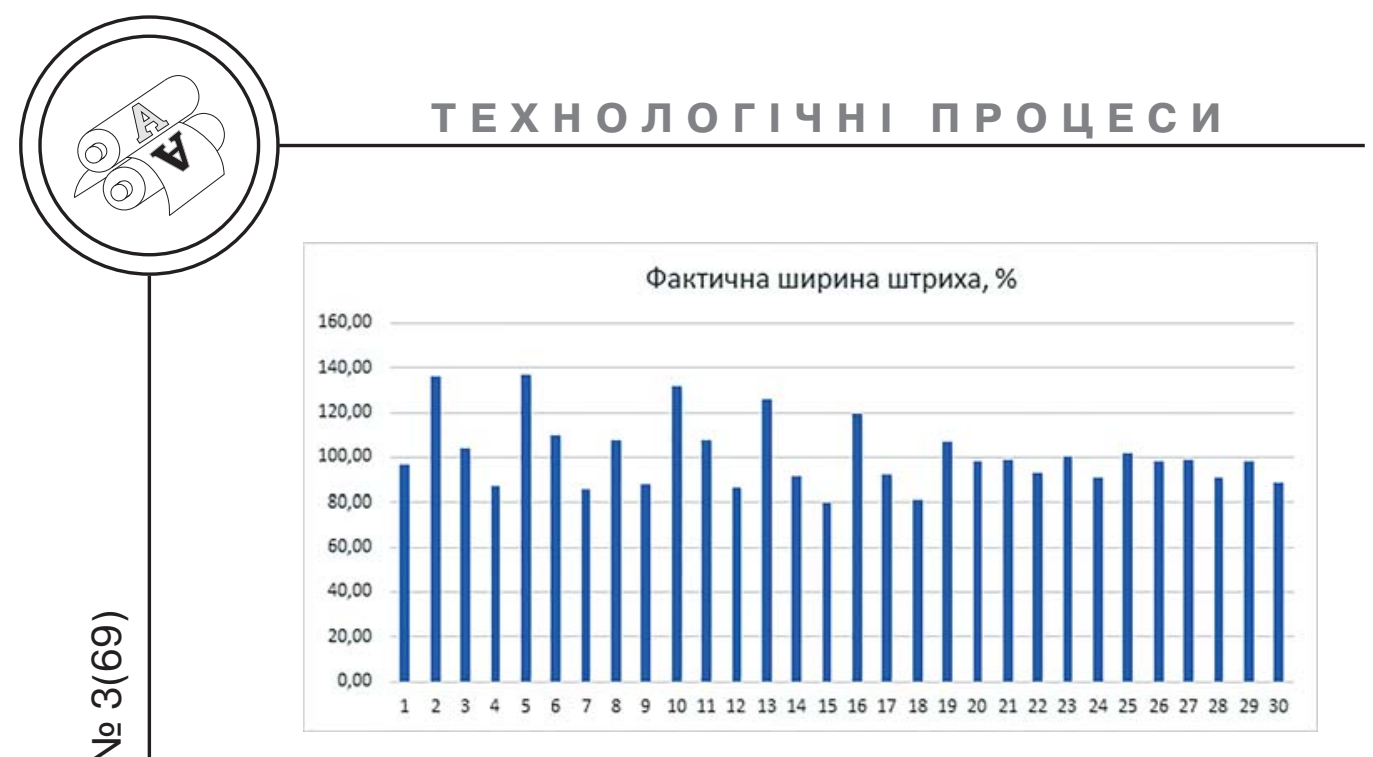

Рис. 1. Фактична ширина штрихів модельної форми порівняно із запроектованим профілем

ширини штриха (80-130 \%) запроектованому (рис. 1). Фактична глибина штриха змінюється суттєвіше - від 60 \% від запроектованого до майже 200 \% (рис. 2). Негативним фактором $є$ те, що така глибина досягається за рахунок краплеподібної видовженої форми дна штриха, котра утворюється через неправильне фокусування лазерного випромінювання і утворення потужного теплового ядра усередині штриха під час гравіювання на перетяжці каустики випромінювання. В окремих випадках ці краплеподібні виступи відокремлені від дна штриха шаром металу 20-30 мкм.

Результати бального оцінювання поверхні стінок штриха за розробленою методикою (рис. 3) показали, що зниження потужності випромінювання дозволяє як забезпечити кращу якість відтворення геометричних параметрів штриха (рис. 4), так і забезпечити кращу якість поверхні штриха (рис. 5).

Останнє є особливо важливим фактором забезпечення належного рівня адгезії захисного покриття до латунної основи.

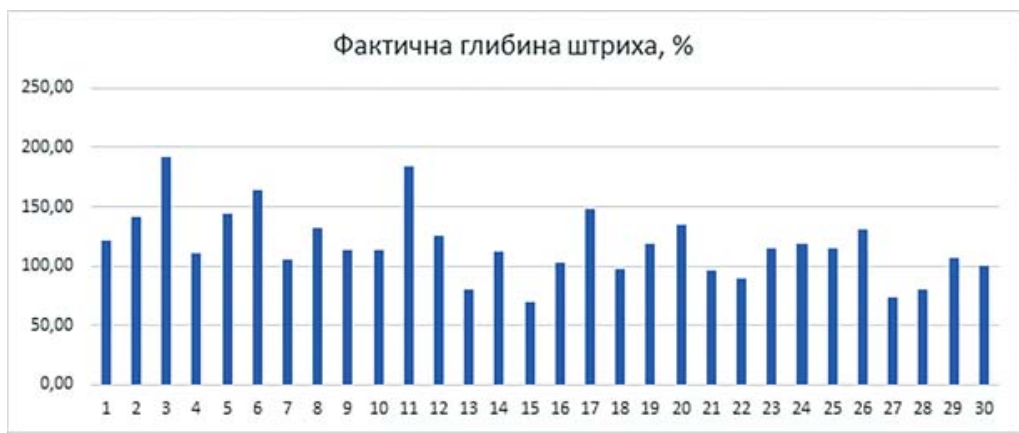

Рис. 2. Фактична глибина штрихів модельної форми порівняно із запроектованим профілем 


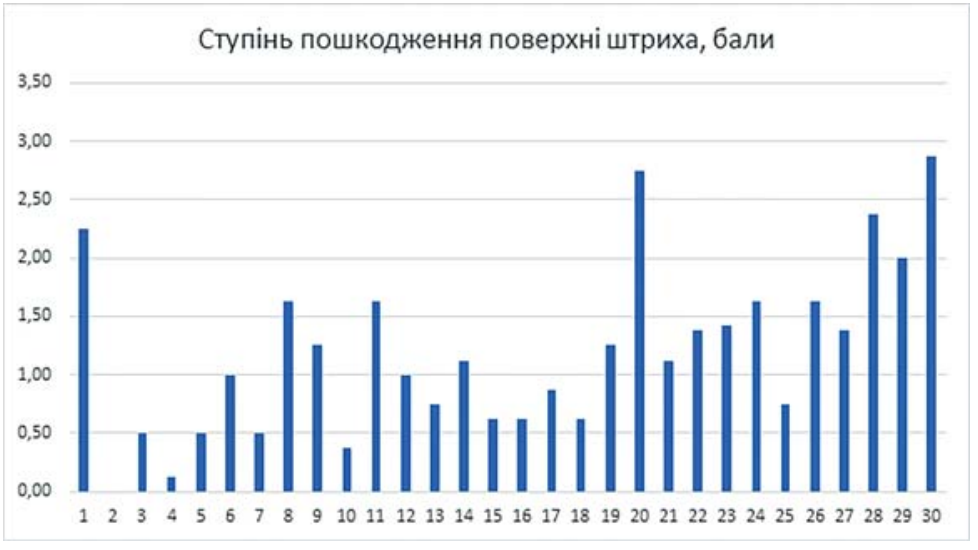

Рис. 3. Ступінь пошкодження штрихів модельної форми в балах

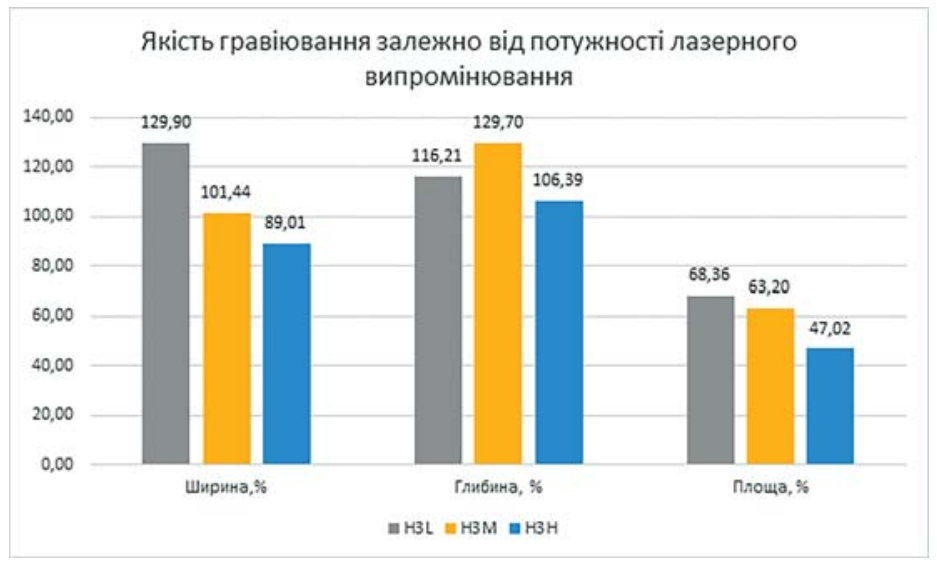

Рис. 4. Геометричні параметри штрихів модельної форми в балах залежно від потужності випромінювання
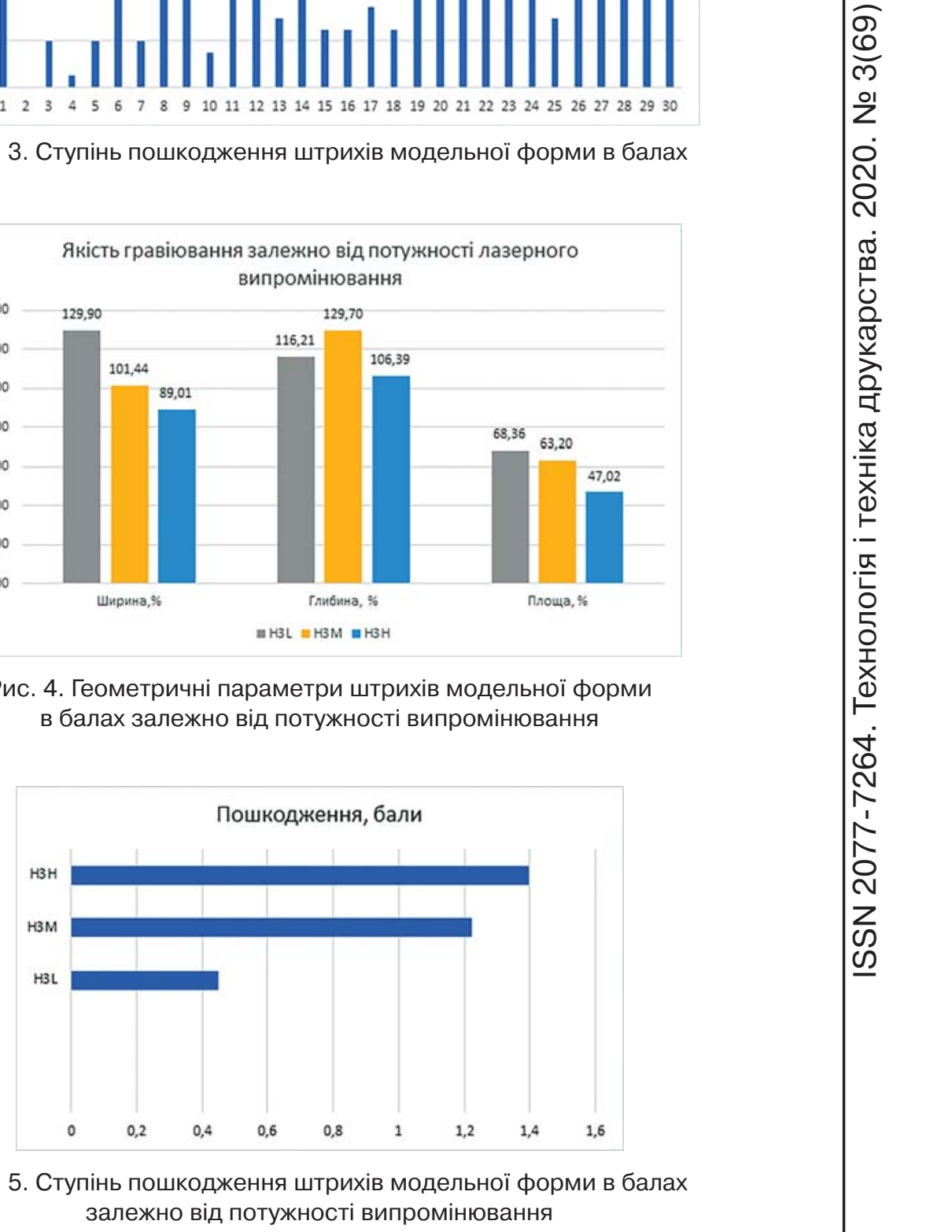

Рис. 5. Ступінь пошкодження штрихів модельної форми в балах залежно від потужності випромінювання 


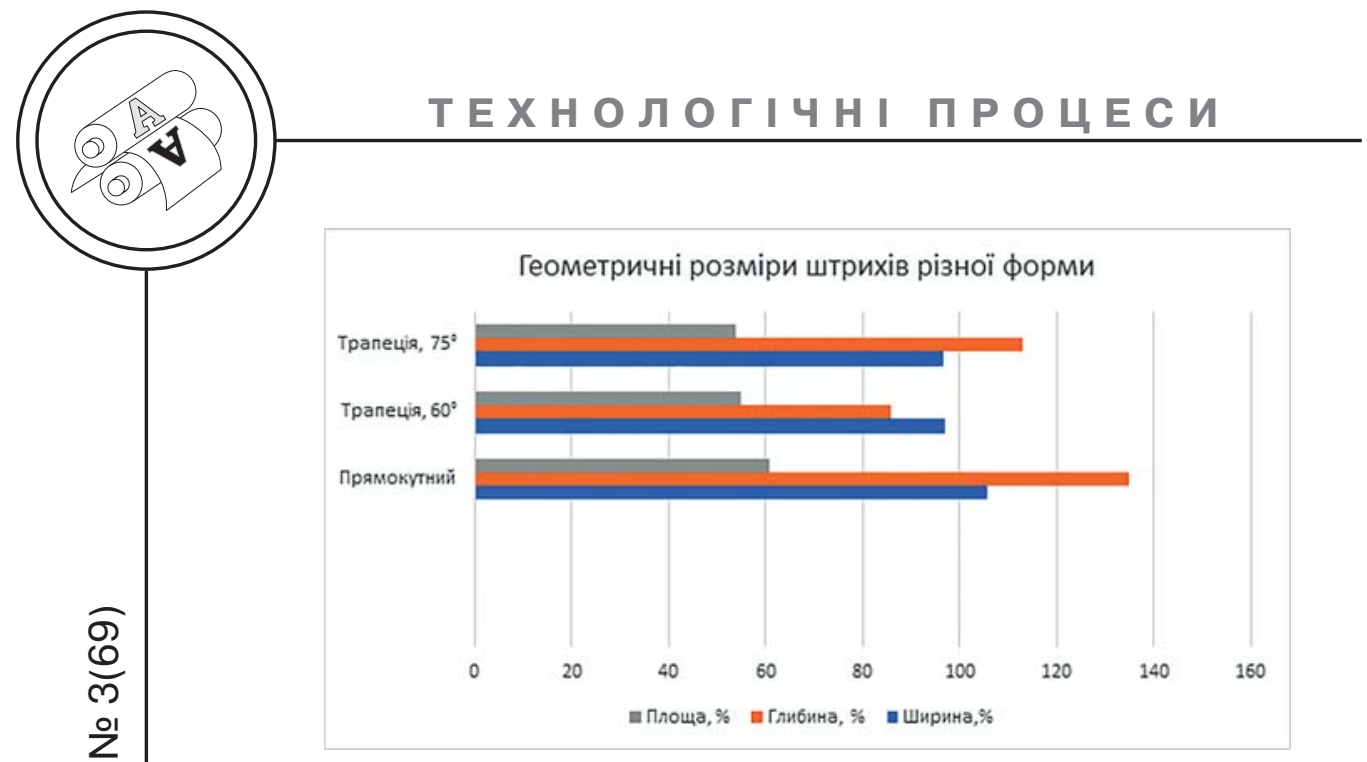

Рис. 6. Геометричні параметри штрихів модельної форми в балах залежно від запроектованої форми штриха

3 погляду відтворення геометричної форми штрихів кращі параметри мають трапецієподібні профілі (рис. 6). 3 погляду якості поверхні штрихів - прямокутні профілі (рис. 7).

\section{Висновки}

Дослідження методом оптичної металографії шліфів гравійованих штрихів тридцяти видів, що відрізнялися запроектованим профілем (глибиною (20-100 мкм), шириною (30-100 мкм), кутом нахилу стінок штриха $\left.\left(60^{\circ}-90^{\circ}\right)\right)$ та потужністю гравіювання, утворених методом DLE на латунній пластині, показало, що всі гравійовані штрихи зразка мають суттєві відхилення від заданого геометричного профіля і зазвичай є несиметричними.

Припущення, що особливості обробки матеріалу форми лазе-

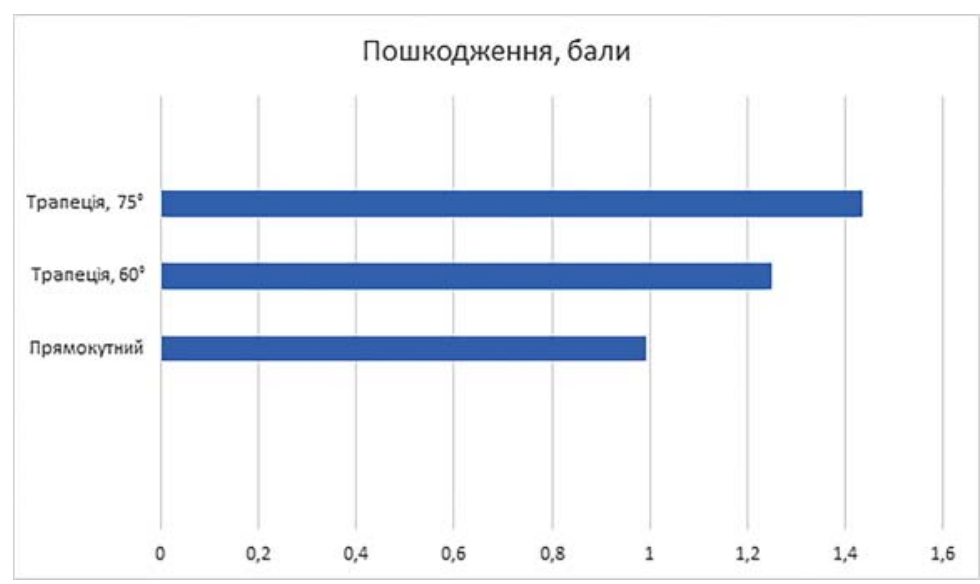

Рис. 7. Ступінь пошкодження штрихів модельної форми в балах залежно від запроектованої форми штриха 
ром під час DLE, зокрема, вплив на шорсткість оброблюваних поверхонь та утворення напливів, можуть впливати на адгезію захисного покриття знайшло повне підтвердження через дослідження мікрошліфів гравійованих латунних форм.

В експериментальних дослідженнях встановлено, що, незважаючи на суттєві відмінності профіля, що був отриманий гравіюванням, і запроектованого, з погляду можливої тактильності відбитків (найсуттєвішого параметру інтагліодруку), переважна більшість режимів виготовлення і профілів забезпечує достатньо високу відповідність ширини штриха (80-130 \%) запроектованому. Глибина штриха змінюється суттєвіше - від 60 \% від запроектованого до майже $200 \%$. Через суттєве відхилення профілю від запроектованого площа перети- ну штрихів перебуває в межах 40-90 \% від запроектованого. Найкращі геометричні параметри мають прямокутні штрихи невеликого розміру. 3 погляду відтворення геометричної форми штрихів кращі параметри мають трапецієподібні профілі. 3 погляду якості поверхні штрихів - прямокутні профілі.

Зниження потужності випромінювання дозволяє як забезпечити кращу якість відтворення геометричних параметрів штриxa, так і забезпечити кращу якість поверхні штриха. Останнє є особливо важливим фактором забезпечення належного рівня адгезії захисного покриття до латунної основи, тобто в подальшому - вищої тиражостійкості. Таким чином, стан поверхні штрихів $є$ ще одним додатковим фактором забезпечення зносостійкості форм DLE + PVD.

\section{Список використаної літератури}

1. De Heij H. Banknote design for retailers and public / H. de Heij // DNB Occasional Studies - De Nederlandsche Bank NV, 2010. Vol. 8 (4). P. 161-164.

2. De Heij H. Designing Banknote Identity / H. de Heij // DNB Occasional Studies - De Nederlandsche Bank NV, 2012. Vol. 10 (3). P. 268-293. https://www.dnb.nl/binaries/DNB OS 1003300836 ebook17MB tcm46278967.pdf.

3. De Heij H. Use-centred Design of Banknotes. Balancing the Use and the Experience / H. De Heij // IBDA INSIGHT. 2016. Vol. 12. Issue 12. P. 53-55. International Banknote Designers Association, November 2016.

4. Van der Horst, F. Does Banknote Quality Affect Counterfeit Detection? Experimental Evidence from Germany and the Netherlands / Frank van der Horst, Martina Eschelbach, Susann Sieber and Jelle Miedema // Jahrbücher für Nationalükonomie und Statistik. 2017. Vol. 237 (6). P. 469-497. DOI: https:// doi.org/10.1515/jibnst-2017-0122.

5. Van der Horst, F. Perception of public security features on euro banknotes; a qualitative study on confidence and authenticity / Van der Horst, F., H. de Heij, J. Miedema, and M. van der Woude (2017) // IBDA INSIGHT. 2017. Vol. 13. P. 53-55.

6. Banknotes: under- or over-featured? / Infosecura Banknote Printing [Electron. resource]. November 2014. No. 62. P. 6-9. Access link: http://www. securityprinters.org/dwl/Infosecura62.pdf. 
7. Bender K. W. Moneymakers. The secret world of banknote printing / K. W. Bender. Wiley-VCH, 2006. $317 \mathrm{p}$.

8. Interpol Resolution No AGN/67/RES/11: 9th International Conference on Currency Counterfeiting, the ICPO-Interpol General Assembly, 67th session. [Electron. resource]. Cairo, Egypt. October 22-27, 1998. Access link: https://www.interpol.int/content/dow.

9. Treinen $\mathrm{H}$. Research endorses the value of two-sided intaglio / H. Treinen // Currency News. February 2005. Vol. 3 (2). P. 10-11.

10. H. Deinhammer. Direct laser engraving of intaglio printing plates / Harald Deinhammer, Franz Loos, Daniel Schwarzbach and Peter Fajmann // Proc. SPIE 5310, Optical Security and Counterfeit Deterrence Techniques V, (3 June 2004); https://doi.org/10.1117/12.526899.

11. H. Deinhammer. The implication of direct laser engraved intaglio plates on banknote security / Harald Deinhammer, Daniel Schwarzbach, Rudolf Kefeder and Peter Fajmann // Proc. SPIE 6075, Optical Security and Counterfeit Deterrence Techniques VI, 607503 (9 February 2006); https://doi.org/10.1117/12.643902.

12. M. Grimsley. Automated inspection of intaglio plate measurement for U.S. currency / Max Grimsley, James E. Hess, Mark Poulsen, Ken Rankin, David Curtis and Donald Bayer // Proc. SPIE 4677, Optical Security and Counterfeit Deterrence Techniques IV, (19 April 2002); https://doi.org/10.1117/12.462735.

13. Пат. 20110250410 Канада, МПК В32B 03/10, C08L 33/08, B41M 01/12, B05D 03/06. Method and composition for printing tactile marks and security document formed therefrom / T. P. Rygas, Th. Thurailingam, S. Crisan, N. J. Sylvain; заявник і патентовласник Canadian Bank Note Company, Limited; заявл. 21.12.2009; опублік. 26.10.2011.

14. Пат. 20040061325 Канада, МПК В42D15/00. Printed security device and method / E. A. Lyen, L. M.-F. Suzzarini; заявник і патентовласник Canadian Bank Note Company, Limited; заявл. 07.09.2002; опублік. 01.04.2004.

15. Пат. 2384890 США, МПК В41F 13/187, B41M 3/14, B41M 1/10, B41N 10/04. Impression cylinder for intaglio printing and intaglio printing process / M. Gygi; заявник і патентовласник KBA-Giori S.A.; заявл. 07.05.2010 р.; опублік. 28.08.2011.

16. Пат. 20110058509 США, МПК В29С35/08. Method and system for manufacturing intaglio printing plates for the production of security papers / J. Perrier; № 12/992522; заявник і патентовласник KBA-GIORI S.A.; заявл. 5.05.2009; опублік. 24.03.2011.

17. Киричок Т. Ю. Система формування тиражостійкості форм інтагліодруку / Т. Ю. Киричок, В. А. Баглай // Технологія і техніка друкарства. 2019. № 3(65). C. 15-24. DOI: https://doi.org/10.20535/2077-7264.3(65). 2019.196565.

18. Киричок Т. Ю. Методика автоматизованого оцінювання якості технологічної операції прямого лазерного гравіювання форм інтагліодруку / Т. Ю. Киричок, В.А.Баглай, А. А. Безпалий, П. Г. Регіда // Технологія і техніка друкарства. 2019. № 4(66). C. 31-41. DOI: https://doi.org/10.20535/20777264.4(66).2019.208868.

19. Роїк Т. А. Композиційні підшипникові матеріали для підвищених умов експлуатації: монографія / Т. А. Роїк, П. О. Киричок, А. П. Гавриш. К.: НТУУ «КП|». 2007. 404 c. 
20. ISO 14577-1:2015. Metallic materials - Instrumented indentation test for hardness and materials parameters - Part 1: Test method.

21. ДСту 7175:2010 Метали і сплави. Методи металографічного контролювання. Терміни та визначення понять; ISO/CD TR 20580.

22. Preparation of metallographic specimens; ISO 4499-1:2008(en). Hardmetals - Metallographic determination of microstructure - Part 1: Photomicrographs and description.

23. ISO 3057:1998(en). Non-destructive testing - Metallographic replica techniques of surface examination.

\section{References}

1. De Heij, H. (2010). Banknote design for retailers and public. Journal of DNB Occasional Studies - De Nederlandsche Bank NV, Vol. 8 (4), 161-164 [in English].

2. De Heij, H. (2012). Designing Banknote Identity. Journal of DNB Occasional Studies - De Nederlandsche Bank NV, Vol. 10 (3), 268-293. Retrieved from https://www.dnb.nl/binaries/DNB_OS_1003_300836_ebook17MB_tcm46278967.pdf [in English].

3. De Heij, H. (2016). Use-centred Design of Banknotes. Balancing the Use and the Experience. Journal of IBDA INSIGHT, Vol. 12, Issue 12, 53-55 [in English].

4. Van der Horst, F. \& Eschelbach, M. \& Sieber, S. \& Miedema J. (2017). Does Banknote Quality Affect Counterfeit Detection? Experimental Evidence from Germany and the Netherlands. Journal of Jahrbücher für Nationalükonomie und Statistik, Vol. 237 (6), 469-497. DOI: https://doi.org/10.1515/jbnst-20170122 [in English].

5. Van der Horst, F. \& de Heij, H. \& Miedema, J. \& van der Woude, M. (2017). Perception of public security features on euro banknotes; a qualitative study on confidence and authenticity. Journal of IBDA INSIGHT, Vol. 13, 53-55 [in English].

6. (2014). Banknotes: under- or over-featured? Journal of Infosecura Banknote Printing, 62, 6-9. Retrieved from http://www.securityprinters.org/ dwl/Infosecura62.pdf [in English].

7. Bender, K. W. (2006). Moneymakers. The secret world of banknote printing. Wiley-VCH, 317 p. [in English].

8. (1998). Interpol Resolution No AGN/67/RES/11. Journal of 9th International Conference on Currency Counterfeiting, the ICPO-Interpol General Assembly. Retrieved from https://www.interpol.int/content/dow [in English].

9. Treinen, H. (2005). Research endorses the value of two-sided intaglio. Journal of Currency News, Vol. 3 (2), 10-11 [in English].

10. Deinhammer, H. \& Loos, F. \& Schwarzbach D. \& Fajmann, P. (2004). Direct laser engraving of intaglio printing plates. Journal of Proc. SPIE 5310, Optical Security and Counterfeit Deterrence Techniques V. Retrieved from https://doi.org/10.1117/12.526899 [in English].

11. Deinhammer, H. \& Schwarzbach, D. \& Kefeder, R. \& Fajmann, P. (2006). The implication of direct laser engraved intaglio plates on banknote security. Journal of Proc. SPIE 6075, Optical Security and Counterfeit Deterrence Techniques VI, 607503. Retrieved from https://doi.org/10.1117/12.643902 [in English].

12. Grimsley, M. \& Hess, J. E. \& Poulsen, M. \& Rankin, K. \& Curtis, D. \& Bayer, D. (2002). Automated inspection of intaglio plate measurement for U.S. 
currency. Journal of Proc. SPIE 4677, Optical Security and Counterfeit Deterrence Techniques IV. Retrieved from https://doi.org/10.1117/12.462735 [in English].

13. Rygas, T. P. \& Thurailingam, Th. \& Crisan, S. \& Sylvain, N. J. Method and composition for printing tactile marks and security document formed therefrom // Patent 20110250410 Canada. Publish 26.10.2011 [in English].

14. Lyen, E. A. \& Suzzarini, L. M.-F. Printed security device and method // Patent 20040061325 Canada. Publish 01.04.2004 [in English].

15. Gygi, M. Impression cylinder for intaglio printing and intaglio printing process // Patent 2384890 USA. Publish 28.08.2011 [in English].

16. Perrier, Ј. Пат. Method and system for manufacturing intaglio printing plates for the production of security papers // Patent 20110058509 USA. Publish 24.03.2011 [in English].

17. Kyrychok, T. Yu. \& Bahlai, V. A. (2019). Systema formuvannia tyrazhostiikosti form intahliodruku [System of Intaglio Plate Run-Length Creation]. Journal of Tekhnolohiia i tekhnika drukarstva, 3(65), 15-24. DOI: https://doi.org/ 10.20535/2077-7264.3(65).2019.196565 [in Ukrainian].

18. Kyrychok, T. Yu. \& Bahlai, V. A. \& Bezpalyi, A. A. \& Rehida, P. H. (2019). Metodyka avtomatyzovanoho otsiniuvannia yakosti tekhnolohichnoi operatsii priamoho lazernoho hraviiuvannia form intahliodruku [Method of Automated Quality Assessment for Technological Operation of Direct Laser Engraving of Intaglio Printing Plates]. Journal of Tekhnolohiia i tekhnika drukarstva, 4(66), 31-41. DOI: https://doi.org/10.20535/2077-7264.4(66).2019.208868 [in Ukrainian].

19. Roik, T. A. \& Kyrychok, P. O. \& Havrysh, A. P. (2007). Kompozytsiini pidshypnykovi materialy dlia pidvyshchenykh umov ekspluatatsii [Composite Bearing Materials for Increased Operating Conditions]. Kyiv: NTUU 'KPI', 404 p. [in Ukrainian].

20. ISO 14577-1:2015. Metallic materials - Instrumented indentation test for hardness and materials parameters - Part 1: Test method [in English].

21. Metaly i splavy. Metody metalohrafichnoho kontroliuvannia. Terminy ta vyznachennia poniat [Metals and Alloys. Methods of Metallographic Control. Terms and Definitions]: DSTU 7175:2010 (ISO/CD TR 20580) [in Ukrainian].

22. Preparation of metallographic specimens; ISO 4499-1:2008(en). Hardmetals - Metallographic determination of microstructure - Part 1: Photomicrographs and description [in English].

23. ISO 3057:1998(en). Non-destructive testing - Metallographic replica techniques of surface examination [in English].

Research by optical metallography of engraved strokes of thirty types, which are different in the designed profile (depth $(20-100 \mu \mathrm{m})$, width (30-100 $\mu \mathrm{m})$, angle of inclination of the walls of the stroke $\left.\left(60^{\circ}-90^{\circ}\right)\right)$ and the laser's engraving power, showed that all the engraved strokes of the sample have significant deviations from the specified geometric profile and are usually asymmetric. 
Since the condition of the surface of the strokes is another additional factor in ensuring the wear resistance of DLE + PVD forms, to take into account this parameter, the principles of scoring the surface of the strokes were developed based on comparison with the sample on a 5-point scale.

Keywords: intaglio printing; direct laser engraving; space element; printing element; engravings; run-length; brass.

Рецензент - Н. Л. Талімонова, канд. техн. наук, доц., КПІ ім. Ігоря Сікорського 